\title{
Police powers to obtain information about patients
}

\author{
A.M.P. Kellam
}

The law in this area is governed by the Police and Criminal Evidence Act of 1984, often referred to as, 'PACE'. I have recently been involved in an appeal which has hopefully clarified the law in this area. The case which was finally heard at the Royal Courts of Justice on 7 April 1993, is referred to as: The Queen-v-Cardiff Crown Court, Ex Parte Kellam A.M.P.

On 21 December 1990 a murder occurred approximately two miles from our hospital. The body of a young woman had been stabbed 83 times was found in a stream. To date no one has been charged with this offence. The police have in their possession DNA material and they are systematically trying to match it against all possible suspects. They have started with men who were in the nightclub she was in on the same night and men who live in the same area. I believe they have so far obtained some 2,000 samples. The procedure for obtaining these samples is somewhat complex as recently a murderer evaded detection for a considerable period of time by getting someone else to give his name and address and thus supply a DNA sample which did not match.

At the beginning of the investigation the police obtained a statement from a witness who had seen, in woods near the site of the homicide, a young man behaving so oddly that he thought he must be a patient from our hospital on day release. The police therefore contacted the hospital and asked for a list of all patients who had been on leave for the relevant days. We were able to prepare such a list from records which we keep to enable our administration to rapidly respond to questions from the Department of Health and Social Security as to whether a person has been on leave on a certain day and is therefore entitled to additional benefit.

As consultant forensic psychiatrist I was asked to deal with the matter on behalf of my colleagues and replied that we had such a list which in my view had been extracted from the patients' individual medical records but now existed on a separate sheet of paper. I pointed out that records of the patients' movements were kept for the purpose of National Insurance payments and in my view this did not constitute a separate register. I finally said that in order to be seen to be protecting our patients' confidentiality. I could only release the list if ordered to do so by a Court under the appropriate act.

As a result of my reply an application for a Special Procedure Order was made in the proper form to the Cardiff Crown Court by the Crown Prosecution Service. South Glamorgan Health Authority provided me with legal advice and representation.

We maintained that under the Police and Criminal Evidence Act, the list was excluded material and, therefore, should not be released.

On 18 May 1992 the original case was heard and an Order made that the list was not "excluded material" but only "special procedure material" and that it should be produced limited to male patients between the ages of 15 and 55 years.

Section Eleven of the Police and Criminal Evidence Act, divides material the police might seek access to into three groups. "Special procedure material" is most professional and journalistic records. Some of these have been made "excluded material" and this is defined in PACE with regard to medical records as, "Documentary and other records concerning an individual (whether living or dead) who can be identified from them and relating - a) to his physical or mental health." There are a large number of other headings.

The issue to be decided by the Appeal Court was, therefore, whether the records of patients' movements which we kept for the purpose of liaison with the Department of Health and Social Security or presumably for any other purposes, related to their physical, or in this case mental health.

It was agreed if our submission was correct that it would apply equally to any register kept at a hospital recording the comings and goings of patients. It was also agreed that production of the document would enable the police to identify persons with reference to the fact that they had suffered or were suffering from a mental illness. 
The appeal judgement noted that the words, "Relating to any matter in question," had been given a wide meaning in Comp. Financeire -vThe Peruvian Guano Company (1882), II Queen's Bench Division 55, and this compelled the learned judges to conclude that the term, "Relate to the mental health of a person," had a very wide meaning and was not confined to clinical, nursing or surgical notes of treatment. The second judge noted that records of admission and discharge from a clinic would often identify the aspect of health for which the person had been a patient.

Both judges, therefore, finally upheld the submission that all these records were "excluded material" within the definition of PACE and could, therefore, only be obtained if they would justify the issue of a search warrant which would, in effect, as I understand it, mean only if they would be likely to be valuable evidence against an individual already known to the police.

The judgement means that the police do not have a right of access to medical records under most circumstances, which is of great importance for reassuring patients about the confidentiality of the information they entrust to us. Obviously nothing in this judgement should ever discourage a doctor from co-operating with the police in the investigation of serious crime and considering in individual cases whether the particular circumstances justify releasing information to the police if this could subsequently be justified as a proper breach of professional confidence when facing either a claim for damages brought by the patient or before the General Medical Council or other disciplinary body.

The decision, however, as to whether the public interest outweighs the individual's right to confidentiality has clearly been placed with the doctor involved and is a decision which has to be taken according to the circumstances of each individual case. I am now arranging with the police to contact the patients concerned and invite them to co-operate with this important investigation.

A. M. P. Kellam, Consultant Psychiatrist, Untversity Hospital of Wales, Cardiff CF4 4XW

\title{
Forthcoming reform of Irish mental health legislation
}

\author{
J.J. Brophy
}

A new Mental Health Act to replace the 1945 law is awaited presently in the Republic of Ireland, following submissions from diverse groups elicited by the 1992 Green Paper on Mental Health. The Green Paper has been widely welcomed as a comprehensive and thoughtful document. Review of the 1945 Act is long overdue in the face of international developments in the field. Most influential to the thinking underlying the proposals were the 1991 UN Principles for the Protection of Persons with Mental Illness and the 1983 Council of Europe Recommendation. The stated aims of the reforms include classification of the indications for committal to hospital, reduction in the number of committals, the provision of new review procedures for committal decisions, and perhaps to balance the emphasis, to provide fresh impetus and a statutory framework for the development of community services for all patients. In reply the Irish Division of the Royal College of Psychiatrists made a detailed submission, adopting a pragmatic and cautious approach, and included position papers summarised already in the Psychiatric Bulletin. (Royal College of Psychiatrists, 1993).

Difficulties in defining mental disorder for the purposes of committal have been addressed in some novel ways in the Green Paper. The wording of "serious likelihood of immediate harm" seeks to escape the thorny problem of the dangerousness criterion, without relying on treatability alone as the standard. The Irish Division liked this wording and added to the novelty by suggesting that persons with a diagnosis of personality disorder might be committed with the possible exception of most psychopathic 